\title{
Structure Antimutagenicity Relationship of Anthraquinones
}

Magdy MD Mohammed*

Department of Pharmacognosy, National Research Centre, Dokki, Cairo, Egypt

\begin{abstract}
Naturally occurring anti-mutagenic principles present in plants, human diet and other sources have protective effects against mutagens. Anthraquinones (AQs) considered one of the major plant phenolic pigments that contain many members, have evidenced the capability for inhibiting the mutagenicity toward Salmonella typhimurium of a number of mutagens. Not only genotoxicity/carcinogenesis is caused by mutagens but also the inception and pathogenesis of several chronic degenerative diseases. The present review attempts to furnish a brief overview on structure-antimutagenicity relationships of natural and synthetic anthraquinones.
\end{abstract}

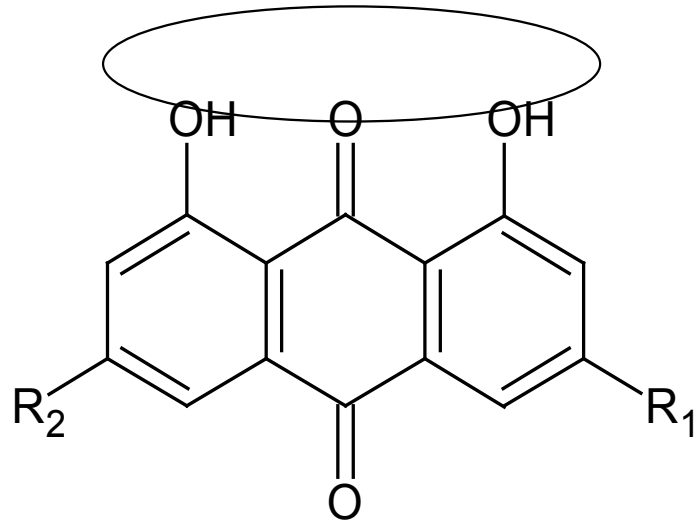

The affinity regions of hydrophobic and coplaner anthraquinones for interacting with CYP1A1

Keywords: Mutation; Mutagenesis; Anti-mutagenic/Anti-carcinogenic; Anthraquinones (AQs); Salmonella typhimurium; Structureactivity relationship

\section{Introduction}

Mutation refers to a heritable change in nucleotide sequence or number, which occurs due to an alteration in the sequence of the code in a gene due to change, removal or insertion of one or more bases in a gene, and resulting in an altered gene product. This may be expressed by the change in the structure of a protein which alters or abolishes its enzymatic properties [1].

Mutation occurs spontaneously or may be induced by environmental, industrial, dietary and natural chemicals; it is a cause of innate metabolic defects in cellular systems, triggering morbidity and mortality in living organisms. Mutations cause permanent alteration in DNA structure, which have been implicated in the etiopathology of cancer and other degenerative diseases [2]. A plethora of synthetic and natural substances are known to act as mutagenic, co-carcinogenic and/or carcinogenic agents. These agents produce a variety of lesions in DNA including strand break, base damage and dimerization of bases. De Flora et al. [3] reported that, mutation in somatic cells is not only involved in the carcinogenesis but can also cause genetic disorders and several other degenerative disorders [3,4], the mutagenic effects of genotoxic chemicals are additive, cumulative and sometimes irreversible [1].

Anti-mutagens are chemicals that reduce the mutagenicity of physical and chemical mutagens [5]. Antimutagens can be classified into two categories based on the initiation site of antimutagenicity; Desmutagens which are blocking agents and/or scavengers of radicals that are capable of inactivate the mutagens partially or fully by enzymatic or chemical interaction before the mutagen attacks the genes outside the cell. Bioantimutagens 'true antimutagens' increase the fidelity of DNA replication, promote the re-pair of DNA damage, suppress the evolution of the neoplastic process and/or are involved in inhibition of error-prone re-pair [6,7].

The mechanisms by which antimutagens work can be classified broadly [8] into; Chemical or enzymatic inactivation: Refers to a group of chemicals that directly inactivate the mutagens by acting on DNA, proteins and enzymes i.e., indole-3-carbinol (Figure 1) which inhibits cytochrome P-450 enzymes. Glutathione transferase (Inducers of phase-II metabolic enzymes) tends to inhibit a wide range of target carcinogens i.e., isothiocyanates such as benzyl isothiocyanate (Figure 1) and antioxidants such as 2, 3-tert butyl-4-hydroxyanisole (BHA). Prevention of the formation of active species: Some mutagens that react with DNA in its active form require metabolic activation or bio-activation to become active, i.e., $\mathrm{N}$-nitro compounds are often formed in the stomach through a reaction form nitrite and secondary or tertiary amines. Scavenging: The dietary mutagens remain intact 'with no ability to react with DNA' after scavenging by desmutagens, i.e., chlorophyllin. Antioxidant and free radical scavenging: Reactive

*Corresponding author: Magdy Mostafa Desoky Mohammed, Department of Pharmacognosy and Chemistry of Medicinal and Aromatic Plants, National Research Centre, Dokki-12622, Cairo, Egypt, Tel: +20233371718; E-mail: melhenawy111@gmail.com

Received May 08, 2016; Accepted June 01, 2016; Published June 06, 2016

Citation: Mohammed MMD (2016) Structure Antimutagenicity Relationship of Anthraquinones. Nat Prod Chem Res 4: 228. doi:10.4172/2329-6836.1000228

Copyright: (c) 2016 Mohammed MMD. This is an open-access article distributed under the terms of the Creative Commons Attribution License, which permits unrestricted use, distribution, and reproduction in any medium, provided the original author and source are credited. 

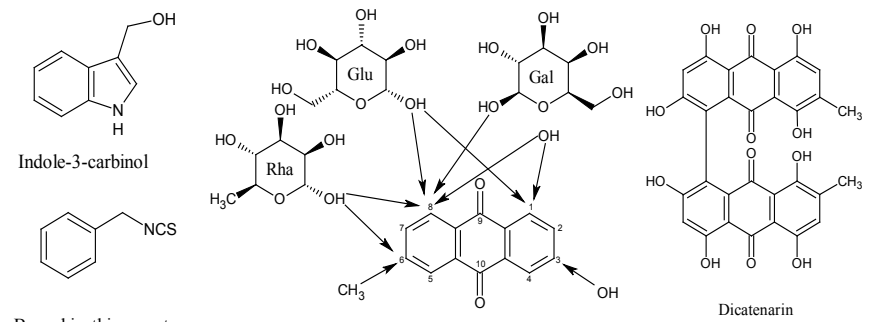

Benzyl isothiocyanate

Figure 1: Basic structure of natural anthraquinone derivatives.

Oxygen Species (ROS) can damage DNA, induce mutations and inhibit DNA re-pair process. That result in the inactivation of certain tumor suppressor genes and leading to cancer. A wide range of antimutagenic agents can readily scavenge most free radicals especially those having a short half-life $\left(\mathrm{OH}^{\cdot}\right)$ i.e., carotenoids, anthraquinones and phenolic compounds.

In the last four decades drug discovery programs have been carried out in order to identify novel bioactive phytocompounds, which helps in, counteracting pro-mutagenic and carcinogenic agents, protect humans against DNA damage and its consequences [9]. There are continued efforts all over the world to explore the rich biodiversity, i.e., edible medicinal plants and other edible non-toxic plants, in pursuit of the most effective phytoantimutagens. These bioactive compounds i.e., phenolics (flavonoids), pigments (AQs), allylsulfides, glucosinolates, phytosterols, protease inhibitors and phytoestrogens, elicit, apart from their antimutagenic and anticarcinogenic properties, additional beneficial effects such as activation of the immune system and/or protection against cardiovascular diseases [10].

The group of chemicals that cause cancer in man and animals are collectively referred to as carcinogens. Environmental pollution is associated with increased risk of cancer [11]. A large number of experimental reports have begun to appear in the scientific literature, wherein increasingly more natural antimutagens have been identified, isolated and found to possess significant antimutation properties [1214]. Moreover, there is an increasing awareness that certain naturally occurring substances in plants and other sources have protective effects against environmental mutagens or carcinogens and also endogenous mutagens. Hence, research work related to the discovery, characterization and use of antimutagenic agents is receiving considerable attention [15].

This review was conducted to highlight on the structure features of a series of natural and synthetic anthraquinones that act as antimutagens.

\section{Chemistry of Anthraquinones (AQs)}

AQs (9, 10-anthraquinone) represent the largest group of natural quinones, the majority of these materials from higher plants and fungi are phenolic [16]. AQs are benzoquinone derivatives in which an aromatic ring is fused to both sides of the benzoquinone [17], they are polyketide in which their nucleus is substituted at C-1 and C-8 with hydroxy groups and may carry an additional hydroxy group at C-3 and one-carbon side chain at C-6 (Figure 1). The most frequently found sugars are glucose or rhamnose at position C-8 or occasionally C-1 in the form of $O$-glycosides [17]. $O$-rhamnose at C-6 and $O$-glucose at C-8 may be found, $O$-digalactoside at C-8 was also reported [18], and a single carbon bond linking two anthraquinone moieties (Figure 1 i.e., dicatenarin).

$A Q s$ are easily reduced in a reversible reaction (Figure 2), anthrone derivatives possess an activated $\mathrm{CH}_{2}$ at $\mathrm{C}-10$ which is able to form C-glycosides i.e., aloin (Figure 3) [19].

\section{Biosynthesis, occurrence and distribution of anthraquinones}

AQs are synthesized by a variety of routes in plants and fungi, e.g., acetate-malonate and/or isochorismate- $\alpha$-ketoglutaric acidmevalonate pathways [20]. Also are produced frequently in plant tissue cultures, e.g., Cinchona species (Rubiaceae) produce at least 30 different anthraquinones [21]. AQs derived from acetate-malonate (polyketide) pathways are widespread in fungi and lichens, but less common in higher plants, e.g., Emodin is among the compounds frequently found in all of these groups. Acetate-malonate-derived AQs usually can be distinguished by their structures because they possess substituents in both benzenoid rings of the anthraquinone nucleus, although there are some exceptions to this generalization [20].

Polyketide-derived AQs have a wide and scattered occurrence in the following families: Monocotyledons- Iridaceae, Liliaceae (Asphodelaceae) (Aloe) and Zingiberaceae; DicotyledonsAnacardiaceae, Asteraceae, Caryophyllaceae, Chenopodiaceae, Clusiaceae, Combretaceae, Ericaceae, Euphorbiaceae, Fabaceae 'Cassia (Senna)', Lythraceae, Polygonaceae, Rhamnaceae, Rhizophoraceae, Saxifragaceae, Scrophulariaceae, Simaroubaceae, Sonneratiaceae, Solanaceae, Urticaceae and Xanthorrheaceae [22]. AQs derived from shikimic and isochorismic acid, are known to occur only in certain dicotyledonous families: Bignoniaceae, Gesneriaceae, Rubiaceae, Scrophulariaceae and Verbenaceae (Gentianales, Lamiales and Scrophulariales) [22].

AQs in which only one ring is substituted are particularly common in the Bignoniaceae, Rubiaceae, and Verbenaceae, but do not appear to occur in fungi, the Polygonaceae, Rhamnaceae, Fabaceae, Caesalpinioideae or Liliaceae (Aloe). These compounds are derived from a pathway similar to that for naphthoquinones, but with subsequent addition of mevalonate-derived units [17].

More than 200 AQs were isolated from flowering plants, and many others were produced by lichens and fungi [21], more of which are occur as glycosides within the plant, but are converted into their aglycones by $\beta$-glucosidases or oxidative processes. The richest families (genus) with AQs are Fabaceae (Cassia), Liliaceae (Aloe), Polygonaceae (Rheum and Rumex), Rhamnaceae (Rhamnus), Rubiaceae (Asperula, Coelospermum, Coprosma, Galium, Morinda and Rubia) and Scrophulariaceae (Digitalis). Members of the Rubiaceae (e.g., madder, Rubia tinctorial) are characterized by brightly coloured anthraquinone pigments that have been used in the past for dyeing and are partly responsible for the colours of several tropical woods. In basic solution, most anthraquinones produce a deep red or blue colour [9].

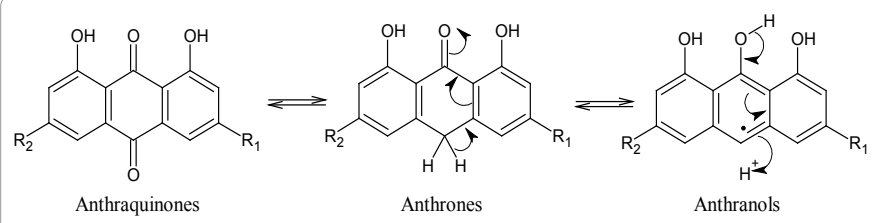

Figure 2: Reduction pathway of anthraquinone.

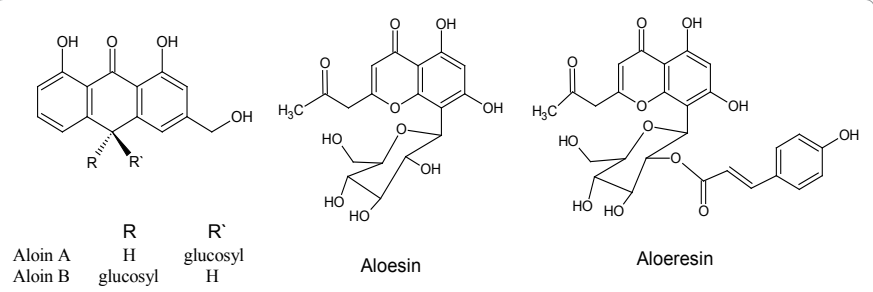

Figure 3: Anthraquinoid compounds isolated from Aloe vera 


\section{The anti-mutagenic/anti-carcinogenic activities of anthraqui- nones}

According to the Ames theory which was firstly presented in 1982, and used to consider the anticancer effect with special emphasizes on application of Salmonela typhimurium (TA10) to identify antimutagenesis and anticancer level of chemicals. In brief, when the prevention percent ranges between $25-40 \%$, mutagenesis effect in this test sample is assumed medium and when the prevention percent is more than 40 , mutagenesis effect of the test sample is strong and in case the prevention percent is less than 25 , mutagenesis effect is negative which the case is true to consider anticancer effect by adding S9 for metabolic activation [23].

It is clear that studies on antimutagenesis make significant contributions to the prevention of cancer (discovery of more anticarcinogens), and the prevention of drug-resistance mutations in disease-causing microorganisms. Such studies have experienced dramatic growth in recent years [24].

Folk medicine has attributed antimutagenic/anticarcinogenic properties of preparations from medicinal plants containing quinones. Quinones for the anthraquinone group were studied for their inhibitory growth effect on cultured malignant cells, which include cultured ovarian, breast, prostate, melanoma, lung, colon and pancreatic cancer cells [25]. For example, eleven AQs isolated from the roots of Morinda elliptica (Table 1, Compounds 3-13) were assayed for their cytotoxic activity. Damnacanthal was cytotoxic towards the MCF-7 (breast carcinoma) and CEM-SS (T-lymphoblastic leukaemia) cell line. Nordamnacanthal was very cytotoxic against the CEM-SS cell lines. Lucidin- $\omega$-methyl ether and rubiadin showed strong cytotoxicity towards (CEM-SS and MCF-7) and (CEM-SS) cells, respectively [26].

Moreover, emodin (Table 1, Compound 49) isolated from the root and rhizome of Rheum palmatum L. and has been reported to exhibit antimutagenic/anticarcinogenic effects. Several studies demonstrated that emodin induces cell apoptosis in human lung squamous carcinoma cell line (CH27), and on cells derived from human colon carcinoma [27]. Rheum officinale $\mathrm{H}$. Bn., a Chinese medicinal plant, also contained large amounts of AQs (Table 1, Compounds 26, 27 and 29), which specifically inhibited one of the carcinogenesis-related enzymes (cytochrome P450) and consequently possess antimutagenic activity through an enzymatic inhibition mechanism [28]. Additionally, chrysophanol, emodin and rhein have been shown to inhibit benzo $[\alpha]$ pyrene-mediated DNA damage in human hepatoma cell line HepG2.

Kuo et al. [29] tested four AQs purified from a Chinese herb Polygonum hypoleucum Onwi (Table 1, Compounds 29, 30, 44 and 45) for their effects on human mesangial cell proliferation in vitro; on a percentage basis emodin had the highest suppressing activity on cells proliferation. Aloe-emodin (28) present in Aloe vera L. leaves, has a specific in vitro and in vivo antineuroectodermal tumor activity. It has been reported to be non-toxic for normal cells, but to possess specific toxicity for neuroectodermal tumor cells, taking into account its unique cytotoxicity profile and mode of action; aloe-emodin might represents a conceptually new lead antitumor drug [30]. More recently, a free-floating cell line has been established from a metastatic lesion of a Merkel cell carcinoma patient, the cell line was characterized by immunocytochemical reactions with antibodies against the epithelial and neuroendocrine antigens. Aloe-emodin significantly inhibited the growth of Merkel carcinoma cells, meriting further investigation as a potential agent for treating these tumors [31]. Previously, Grimaudo et al. [32] had studied the effects of five purified anthraquinoids (Figure 3; Table 1, 28) from Aloe vera L. on human K562 leukaemia, and only aloe-emodin produced reproducible antitumor effects. Shimpo et al. [33] examined the modifying effect of the whole leaf of another species of this genus, Aloe arborescens Miller var. natalensis Berger on azoxymethane (a mutagenic agent) which induced aberrant crypt foci (a putative pre-neoplastic lesions in the rat colorectum, causing colonotropic carcinogenicity), suggesting that this plant has a chemopreventive effect against colon carcinogenesis, at least in the initiation stage, which could be attributed to its content of anthraquinones. Several studies demonstrated that aloin (Figure 3), a natural anthraquinone with potential antitumor activity, was effective on mice bearing solid Erlich carcinoma [34,35]. Furthermore, aloin showed antitumor activity against two epithelial-type tumor cell lines; breast and ovarian [36].

It can be concluded that the number of hydroxyl groups in the anthraquinone nucleus seemed to play an important role in the degree of cell growth inhibition; anthraquinones with two or three hydroxy groups were more effective than those with no hydroxy groups, i.e., 9,10-dioxoanthracene [25]. However, the number of hydroxyl substituents of anthraquinones seems to be less influential on their antimutagenicity rather than the position of the hydroxyl substituent itself. Which appeared clearly that compounds with two meta-hydroxyl groups e.g., nordamnacanthal, lucidin- $\omega$-methyl ether and rubiadin showed strong cytotoxicity against CEM-SS and MCF-7 [26]

Mohammed et al. [37] isolated two anthraquinones (Table 1, Compounds 28 and 42) from Cassia roxburghii Linn. and evaluated their cytotoxicity against HCT-116, MCF-7 and HepG-2, and their antiviral activity against influenza virus- $\mathrm{A}$, the obtained results revealed that aloe-emodin was more potent cytotoxic and antiviral agent than aloe-emodin acetate, this can be attributed to the presence of $\mathrm{CH}_{2} \mathrm{OH}$ group at C-3, which seems to be necessary for the activity along with 1,8-dihydroxy groups. Interestingly, intramolecular hydrogen bonding could occur in anthraquinones leading to more potency. Furthermore, four known AQs (Table 1, Compounds 27, 29, 30 and 39) were isolated from the aerial parts of Rumex acetosa and investigated for their cytotoxicity against A549, SK-OV-3, SK-MEL-2, XF498 and HCY15, and their antimutagenicity by Ames test with Salmonella typhimurium TA98, TA100 and SOS chromotest with E. coli PQ37, together with two synthetic analogues (Table 1, Compounds 40 and 41). In a view of the structure-activity relationship (SAR) correlations [38], no mutagenic activities of the tested compounds were detected, whereas among the tested compounds; emodin strongly inhibited the proliferation of each examined tumor cell line, with $\mathrm{IC}_{50}$ values ranged from 2.94 to $3.64 \mathrm{mg} / \mathrm{mL}$, and showed potent antimutagenic activities with $71.5 \%$ and $53.3 \%$ at the concentration of $0.1 \mathrm{mg} /$ plate against the mutagens, 4-nitro-O-phenylenediamine (NPD) and sodium azide, respectively. Its antigenotoxic activity was also very effective at the final concentration of $10 \mathrm{mg} /$ reaction tube against the mutagens, methylnitronitrosoguanidine (MNNG) and 4-nitroquinoline-1-oxide (NQO) (Figure 4) by SOS chromo test, reducing the induction factors by $19.6 \%$ and $43.5 \%$, respectively [38]. The SAR study suggests that an<smiles>Nc1ccc([N+](=O)[O-])cc1N</smiles><smiles>CN(N=O)C(=N)N[N+](=O)[O-]</smiles><smiles>O=[N+]([O-])c1cc[n+]([O-])c2ccccc12</smiles>

4-Nitro-o-phenylenediamine Methylnitronitrosoguanidine 4-Nitroquinoline 1-oxide

Figure 4: Structures of some mutagens 
Citation: Mohammed MMD (2016) Structure Antimutagenicity Relationship of Anthraquinones. Nat Prod Chem Res 4: 228. doi:10.4172/23296836.1000228

\begin{tabular}{|c|c|c|c|c|c|c|c|c|}
\hline Compounds & $R_{1}$ & $\mathbf{R}_{2}$ & $\mathbf{R}_{3}$ & $\mathbf{R}_{\mathbf{4}}$ & $\mathbf{R}_{5}$ & $\mathbf{R}_{6}$ & $\mathbf{R}_{7}$ & $\mathbf{R}_{8}$ \\
\hline 2) Anthraquinone & $\mathrm{H}$ & $\mathrm{H}$ & $\mathrm{H}$ & $\mathrm{H}$ & $\mathrm{H}$ & $\mathrm{H}$ & $\mathrm{H}$ & $\mathrm{H}$ \\
\hline $\begin{array}{l}\text { 3) 2-formyl-1-hydroxy- } \\
\text { Anthraquinone }\end{array}$ & $\mathrm{OH}$ & $\mathrm{CHO}$ & $\mathrm{H}$ & $\mathrm{H}$ & $\mathrm{H}$ & $\mathrm{H}$ & $\mathrm{H}$ & $\mathrm{H}$ \\
\hline $\begin{array}{l}\text { 4) 1-hydroxy-2-methyl- } \\
\text { Anthraquinone }\end{array}$ & $\mathrm{OH}$ & $\mathrm{CH}_{3}$ & $\mathrm{H}$ & $\mathrm{H}$ & $\mathrm{H}$ & $\mathrm{H}$ & $\mathrm{H}$ & $\mathrm{H}$ \\
\hline 5) Lucidin- $\omega$-methylether & $\mathrm{OH}$ & $\mathrm{CH}_{2} \mathrm{OCH}_{3}$ & $\mathrm{OH}$ & $\mathrm{H}$ & $\mathrm{H}$ & $\mathrm{H}$ & $\mathrm{H}$ & $\mathrm{H}$ \\
\hline 6) Nordamnacanthal & $\mathrm{OH}$ & $\mathrm{CHO}$ & $\mathrm{OH}$ & $\mathrm{H}$ & $\mathrm{H}$ & $\mathrm{H}$ & $\mathrm{H}$ & $\mathrm{H}$ \\
\hline 7) Damnacanthal & $\mathrm{OCH}_{3}$ & $\mathrm{CHO}$ & $\mathrm{OH}$ & $\mathrm{H}$ & $\mathrm{H}$ & $\mathrm{H}$ & $\mathrm{H}$ & $\mathrm{H}$ \\
\hline 8) Rubiadin & $\mathrm{OH}$ & $\mathrm{CH}_{3}$ & $\mathrm{OH}$ & $\mathrm{H}$ & $\mathrm{H}$ & $\mathrm{H}$ & $\mathrm{H}$ & $\mathrm{H}$ \\
\hline 9) Morindone & $\mathrm{OH}$ & $\mathrm{OH}$ & $\mathrm{H}$ & $\mathrm{H}$ & $\mathrm{OH}$ & $\mathrm{CH}_{3}$ & $\mathrm{H}$ & $\mathrm{H}$ \\
\hline 10) Soranjidiol & $\mathrm{OH}$ & $\mathrm{CH}_{3}$ & $\mathrm{H}$ & $\mathrm{H}$ & $\mathrm{H}$ & $\mathrm{OH}$ & $\mathrm{H}$ & $\mathrm{H}$ \\
\hline 11) Rubiadin-1-methylether & $\mathrm{OCH}_{3}$ & $\mathrm{CH}_{3}$ & $\mathrm{OH}$ & $\mathrm{H}$ & $\mathrm{H}$ & $\mathrm{H}$ & $\mathrm{H}$ & $\mathrm{H}$ \\
\hline $\begin{array}{c}\text { 12) Morindone-5-methyl- } \\
\text { Ether }\end{array}$ & $\mathrm{OH}$ & $\mathrm{OH}$ & $\mathrm{H}$ & $\mathrm{H}$ & $\mathrm{OCH}_{3}$ & $\mathrm{CH}_{3}$ & $\mathrm{H}$ & $\mathrm{H}$ \\
\hline 13) Alizarin-1-methylether & $\mathrm{OCH}_{3}$ & $\mathrm{OH}$ & $\mathrm{H}$ & $\mathrm{H}$ & $\mathrm{H}$ & $\mathrm{H}$ & $\mathrm{H}$ & $\mathrm{H}$ \\
\hline 14) Quinizarin & $\mathrm{OH}$ & $\mathrm{H}$ & $\mathrm{H}$ & $\mathrm{OH}$ & $\mathrm{H}$ & $\mathrm{H}$ & $\mathrm{H}$ & $\mathrm{H}$ \\
\hline 15) Alizarin & $\mathrm{OH}$ & $\mathrm{OH}$ & $\mathrm{H}$ & $\mathrm{H}$ & $\mathrm{H}$ & $\mathrm{H}$ & $\mathrm{H}$ & $\mathrm{H}$ \\
\hline 16) Purpurin & $\mathrm{OH}$ & $\mathrm{OH}$ & $\mathrm{H}$ & $\mathrm{OH}$ & $\mathrm{H}$ & $\mathrm{H}$ & $\mathrm{H}$ & $\mathrm{H}$ \\
\hline 17) Anthraflafic acid & $\mathrm{OH}$ & $\mathrm{H}$ & $\mathrm{H}$ & $\mathrm{H}$ & $\mathrm{H}$ & $\mathrm{OH}$ & $\mathrm{H}$ & $\mathrm{H}$ \\
\hline 18) Anthrarufin & $\mathrm{OH}$ & $\mathrm{H}$ & $\mathrm{H}$ & $\mathrm{H}$ & $\mathrm{OH}$ & $\mathrm{H}$ & $\mathrm{H}$ & $\mathrm{H}$ \\
\hline 19) 2-Ethylanthraquinone & $\mathrm{H}$ & $\mathrm{CH}_{2} \mathrm{CH}_{3}$ & $\mathrm{H}$ & $\mathrm{H}$ & $\mathrm{H}$ & $\mathrm{H}$ & $\mathrm{H}$ & $\mathrm{H}$ \\
\hline $\begin{array}{l}\text { 20) 2,3-Dimethyl- } \\
\text { Anthraquinone }\end{array}$ & $\mathrm{H}$ & $\mathrm{CH}_{3}$ & $\mathrm{CH}_{3}$ & $\mathrm{H}$ & $\mathrm{H}$ & $\mathrm{H}$ & $\mathrm{H}$ & $\mathrm{H}$ \\
\hline $\begin{array}{l}\text { 21) 1,4-Dimethyl- } \\
\text { Anthraquinone }\end{array}$ & $\mathrm{CH}_{3}$ & $\mathrm{H}$ & $\mathrm{H}$ & $\mathrm{CH}_{3}$ & $\mathrm{H}$ & $\mathrm{H}$ & $\mathrm{H}$ & $\mathrm{H}$ \\
\hline $\begin{array}{l}\text { 22) } 1,5 \text {-Diamino-4,8- } \\
\text { dihydroxyanthraquinone }\end{array}$ & $\mathrm{NH}_{2}$ & $\mathrm{H}$ & $\mathrm{H}$ & $\mathrm{OH}$ & $\mathrm{NH}_{2}$ & $\mathrm{H}$ & $\mathrm{H}$ & $\mathrm{OH}$ \\
\hline $\begin{array}{l}\text { 23) 1,5-Dihydroxy-4,8- } \\
\text { dinitroanthraquinone }\end{array}$ & $\mathrm{OH}$ & $\mathrm{H}$ & $\mathrm{H}$ & $\mathrm{NO}_{2}$ & $\mathrm{OH}$ & $\mathrm{H}$ & $\mathrm{H}$ & $\mathrm{NO}_{2}$ \\
\hline $\begin{array}{l}\text { 24) 1,4-Diamino-2,3- } \\
\text { dichloroanthraquinone }\end{array}$ & $\mathrm{NH}_{2}$ & $\mathrm{Cl}$ & $\mathrm{Cl}$ & $\mathrm{NH}_{2}$ & $\mathrm{H}$ & $\mathrm{H}$ & $\mathrm{H}$ & $\mathrm{H}$ \\
\hline 25) Danthron or Chrysazin & $\mathrm{OH}$ & $\mathrm{H}$ & $\mathrm{H}$ & $\mathrm{H}$ & $\mathrm{H}$ & $\mathrm{H}$ & $\mathrm{H}$ & $\mathrm{OH}$ \\
\hline 26) Rhein & $\mathrm{OH}$ & $\mathrm{H}$ & $\mathrm{COOH}$ & $\mathrm{H}$ & $\mathrm{H}$ & $\mathrm{H}$ & $\mathrm{H}$ & $\mathrm{OH}$ \\
\hline $\begin{array}{l}\text { 27) Chrysophanol or } \\
\text { Chrysophanic acid }\end{array}$ & $\mathrm{OH}$ & $\mathrm{H}$ & $\mathrm{CH}_{3}$ & $\mathrm{H}$ & $\mathrm{H}$ & $\mathrm{H}$ & $\mathrm{H}$ & $\mathrm{OH}$ \\
\hline 28) Aloe-emodin & $\mathrm{OH}$ & $\mathrm{CH}_{2} \mathrm{OH}$ & $\mathrm{H}$ & $\mathrm{H}$ & $\mathrm{H}$ & $\mathrm{H}$ & $\mathrm{H}$ & $\mathrm{OH}$ \\
\hline 29) Emodin & $\mathrm{OH}$ & $\mathrm{H}$ & $\mathrm{OH}$ & $\mathrm{H}$ & $\mathrm{H}$ & $\mathrm{CH}_{3}$ & $\mathrm{H}$ & $\mathrm{OH}$ \\
\hline 30) Physicon & $\mathrm{OH}$ & $\mathrm{H}$ & $\mathrm{CH}_{3}$ & $\mathrm{H}$ & $\mathrm{H}$ & $\mathrm{OCH}_{3}$ & $\mathrm{H}$ & $\mathrm{OH}$ \\
\hline $\begin{array}{l}\text { 31) Anthrauinone-2- } \\
\text { carboxylic acid }\end{array}$ & $\mathrm{H}$ & $\mathrm{COOH}$ & $\mathrm{H}$ & $\mathrm{H}$ & $\mathrm{H}$ & $\mathrm{H}$ & $\mathrm{H}$ & $\mathrm{H}$ \\
\hline $\begin{array}{l}\text { 32) Anthrauinone-2-sulfonic } \\
\text { Acid }\end{array}$ & $\mathrm{H}$ & $\mathrm{SO}_{3} \mathrm{H}$ & $\mathrm{H}$ & $\mathrm{H}$ & $\mathrm{H}$ & $\mathrm{H}$ & $\mathrm{H}$ & $\mathrm{H}$ \\
\hline 33) Alizarin Red S & $\mathrm{OH}$ & $\mathrm{OH}$ & $\mathrm{SO}_{3} \mathrm{Na}$ & $\mathrm{H}$ & $\mathrm{H}$ & $\mathrm{H}$ & $\mathrm{H}$ & $\mathrm{H}$ \\
\hline 34) 2,3-Dimethylquinizarine & $\mathrm{OH}$ & $\mathrm{CH}_{3}$ & $\mathrm{CH}_{3}$ & $\mathrm{OH}$ & $\mathrm{H}$ & $\mathrm{H}$ & $\mathrm{H}$ & $\mathrm{H}$ \\
\hline $\begin{array}{c}\text { 35) 2-Hydroxymethyl- } \\
\text { Anthraquinone }\end{array}$ & $\mathrm{H}$ & $\mathrm{CH}_{2} \mathrm{OH}$ & $\mathrm{H}$ & $\mathrm{H}$ & $\mathrm{H}$ & $\mathrm{H}$ & $\mathrm{H}$ & $\mathrm{H}$ \\
\hline 36) Tectoquinone & $\mathrm{H}$ & $\mathrm{H}$ & $\mathrm{CH}_{3}$ & $\mathrm{H}$ & $\mathrm{H}$ & $\mathrm{H}$ & $\mathrm{H}$ & $\mathrm{H}$ \\
\hline 37) Frangulin (A) & $\mathrm{OH}$ & $\mathrm{H}$ & rhamnoside & $\mathrm{H}$ & $\mathrm{H}$ & $\mathrm{CH}_{3}$ & $\mathrm{H}$ & $\mathrm{OH}$ \\
\hline 38) Frangulin (B) & $\mathrm{OH}$ & $\mathrm{H}$ & apioside & $\mathrm{H}$ & $\mathrm{H}$ & $\mathrm{CH}_{3}$ & $\mathrm{H}$ & $\mathrm{OH}$ \\
\hline 39) Emodin-8-O-glucoside & $\mathrm{OH}$ & $\mathrm{H}$ & $\mathrm{OH}$ & $\mathrm{H}$ & $\mathrm{H}$ & $\mathrm{CH}_{3}$ & $\mathrm{H}$ & glucoside \\
\hline $\begin{array}{l}\text { 40) 1,8-Dimethoxy-6- } \\
\text { hydroxy-3-methyl- } \\
\text { anthraquinone }\end{array}$ & $\mathrm{OCH}_{3}$ & $\mathrm{H}$ & $\mathrm{CH}_{3}$ & $\mathrm{H}$ & $\mathrm{H}$ & $\mathrm{OH}$ & $\mathrm{H}$ & $\mathrm{OCH}_{3}$ \\
\hline $\begin{array}{l}\text { 41) } 1,6,8 \text {-Trimethoxy-3- } \\
\text { methylanthraquinone }\end{array}$ & $\mathrm{OCH}_{3}$ & $\mathrm{H}$ & $\mathrm{CH}_{3}$ & $\mathrm{H}$ & $\mathrm{H}$ & $\mathrm{OCH}_{3}$ & $\mathrm{H}$ & $\mathrm{OCH}_{3}$ \\
\hline 42) Aloe-emodin-2-acetate & $\mathrm{OH}$ & $\mathrm{H}$ & $\mathrm{CH}_{2} \mathrm{COOCH}_{3}$ & $\mathrm{H}$ & $\mathrm{H}$ & $\mathrm{H}$ & $\mathrm{H}$ & $\mathrm{OH}$ \\
\hline 43) Questin & $\mathrm{OCH}_{3}$ & $\mathrm{H}$ & $\mathrm{OH}$ & $\mathrm{H}$ & $\mathrm{H}$ & $\mathrm{CH}_{3}$ & $\mathrm{H}$ & $\mathrm{OH}$ \\
\hline 44) Physicon-1-O-glucoside & glycoside & $\mathrm{H}$ & $\mathrm{CH}_{3}$ & $\mathrm{H}$ & $\mathrm{H}$ & $\mathrm{OCH}_{3}$ & & \\
\hline 45) Islandicin & $\mathrm{OH}$ & $\mathrm{H}$ & $\mathrm{CH}_{3}$ & $\mathrm{OH}$ & $\mathrm{H}$ & $\mathrm{H}$ & $\mathrm{H}$ & $\mathrm{OH}$ \\
\hline
\end{tabular}

Table 1: AQs with a distinct structure features that exhibited antimutagenic/anticarcinogenic activities. 
additional $\mathrm{OH}$ group at $\mathrm{C}-3$ position in the anthraquinone nucleus may play an important role for their cytotoxicity, and an introduction of $-\mathrm{OH}$ or $-\mathrm{OCH}_{3}$ group at C-3 position is necessary for their antimutagenicity, even though the important $\mathrm{OH}$ groups are bonded at C-1 and C-8 positions [38].

It was also reported that overexpression of Cdc25B (a protein phosphatase) was detected in $32 \%$ of human primary breast cancers tested and the $\mathrm{Cdc} 25$ phosphatases may contribute to the development of human cancer. Therefore, the identification of Cdc25B inhibitors has become an active area for the development of anti-tumor agents [39]. Sung-Gyu et al. [40] investigated the methanolic extract of the roots of Polygonum multiflorum Thunb. (Polygonaceae), and demonstrated that the isolated three AQs; physcion, emodin and questin (Table 1, Compounds 29, 30 and 43), inhibited the enzymatic activity of Cdc25B phosphatase with $\mathrm{IC}_{50}$ values of $62.5,30$, and $34 \mathrm{mg} / \mathrm{mL}$, respectively. Whereas emodin and questin strongly inhibited the growth of human colon cancer cells (SW620) with $\mathrm{GI}_{50}$ (the concentration for $50 \%$ of maximal inhibition of cell proliferation) values of 6.1 and $0.9 \mathrm{mg} /$ $\mathrm{mL}$, respectively. Moreover, commercially available AQs (Table 1, Compounds 26 and 27), chrysophanol and rhein were also inhibit Cdc25B phosphatase with $\mathrm{IC}_{50}$ values of 10.7 and $22.1 \mathrm{mg} / \mathrm{mL}$, respectively.

\section{Anti-mutagenic activity of anthraquinones against ni- troarenes}

Nitroarenes (Figure 5) are compounds generated by the reaction of nitrogen oxides $\left(\mathrm{NO}_{\mathrm{x}}\right)$ with polycyclic aromatic hydrocarbons during an incomplete combustion of organic materials, i.e., combustion engines [41], as well as in the atmosphere [42]. Fluorene, pyrene and fluoranthene are quantitatively prominent among atmospheric polycyclic aromatic hydrocarbons. It is not surprising that nitro derivatives of these compounds are again among the most abundant respective nitroarenes. 2-Nitrofluorene (2-NF) is normally the dominating atmospheric nitroarene, followed by nitrofluoranthenes, for instance, 3-nitrofluoranthene (3-NFA) and nitropyrenes. Among nitropyrenes, 1-nitropyrene (I-NP) is the most abundant compound, and well known to be present in the particle phase of diesel exhaust [43]. Nitroarenes have also been detected in foods [44,45]. Incomplete combustion of foods in the presence of $\mathrm{NO}_{\mathrm{x}}$ favours the formation of nitroarenes, while oxidation of the respective amines is an alternative pathway though of minor importance [46], therefore, human exposure may occur by inhalation as well as through the gastrointestinal tract. Many nitroarenes have been demonstrated to exert mutagenic activities in bacterial and mammalian test systems, but only a few have been proven to be carcinogenic in rodents, among them 2-NF, 3-NFA and 1-NP as well as several dinitro derivatives of these compounds $[43,45,47]$. In addition, these and other nitroarenes may be involved in the aetiology of some human cancers, namely lung and breast $[48,49]$.

Edenharder and Tang [50] investigated various naturally occurring and synthetic AQs (Table 1, Compounds 2, 14-16, 25, 26, 29, 30, 33,34 and 36) for their antimutagenic activities against 2-NF, 1-NP and 3-NFA. It can be seen that the parent compound anthraquinone as well as tectoquinone with no polar functions were inactive, while the glycosidic AQs (37 and 38) showed only weak antimutagenicity. Dihydroxyanthraquinones, however, such as alizarin, quinizarin and chrysazin, exerted strong antimutagenicity against all nitroarenes investigated, with alizarin being the most potent antimutagenic. The presence of an additional hydroxyl group at C-4 of alizarin (i.e., purpurin) or a sulfo function at C-3 (i.e., alizarin Red S) did not cause major changes. Rhein with one carboxyl and two hydroxyl functions was a potent antimutagen. However, reducing polarity by introduction of methyl groups or methylation of a phenolic hydroxyl group (2, 3-dimethylquinizarin, emodin and physicon) reduced or even eliminated the antimutagenic potency, these effects are best visible with respect to mutagenicity induced by $2-\mathrm{NF}$ in Salmonella.

It became evident that many of these compounds exerted antimutagenicity with distinct structure-activity relationships as follow; First, the impact of the tetracyclic nitroarenes 1-NP and 3-NFA was usually antagonized more effectively than mutagenicity of the tricyclic compound 2-NF. Secondly, antimutagenicity was widely linked to aglycones: glycosides of anthraquinones with various sugars were completely inactive. Most investigated AQs were potent antimutagens against the three nitroarenes tested. Antimutagenicity of extracts of Chinese herbs Rheum palmatum B and Polygonum cuspidatum S [51] against 1-NP was attributed to various polyphenols i.e., emodin. With respect to heterocyclic aromatic amine mutagens in vitro antimutagenic activities in Salmonella have been described for aloe-emodin, chrysophanol, emodin and physicon [52], as well as of various anthraquinones and emodin against benzo[ $\alpha]$ pyrene [53].

\section{Anti-mutagenicity of anthraquinone against heterocyclic aromatic amines}

Under normal household cooking conditions of foods rich in protein, such as meat and fish, a series of heterocyclic aromatic amines (HAAs) are generated (Figure 6). Among them, five compounds are considered to be the principal HAAs consumed within the diet: 2-amino-1-methyl-6-phenylimidazo[4,5- $b]$ pyridine (PhIP), 2-amino9H-pyrido[2,3- $b$ ]indole (AaC), 2-amino-3,8-dimethylimidazo[4,5- $f]$ quinoxaline (MeIQx), 2-amino-3,4,8-trimethylimidazo[4,5- $f]$ quinoxaline (DiMeIQx) and 2-amino-3-methylimidazo[4,5-f] quinoline (IQ) [54]. All these HAAs are mutagenic in the Salmonellal reversion assay and carcinogenic in laboratory animals. IQ, however, warrants special attention since it is among the most potent mutagenic and carcinogenic HAAs $[54,55]$. HAAs were regarded as potential human carcinogens [56], but the real health hazards are still unknown. Persons who live on a usual mixed diet are exposed to these HAAs for nearly an entire lifetime [57]. On the other hand, the HAAs are typical tumor initiators [58] and might represent a lower risk as human

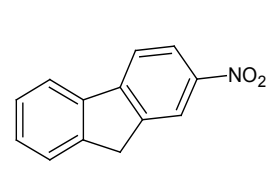

2-Nitrofluorene

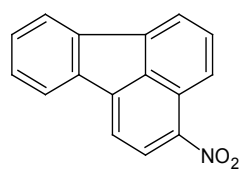

3-Nitrofluoranthene

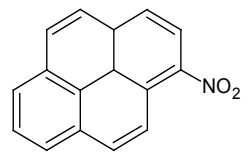

1-Nitropyrene
Figure 5: Structures of some nitroarenes.

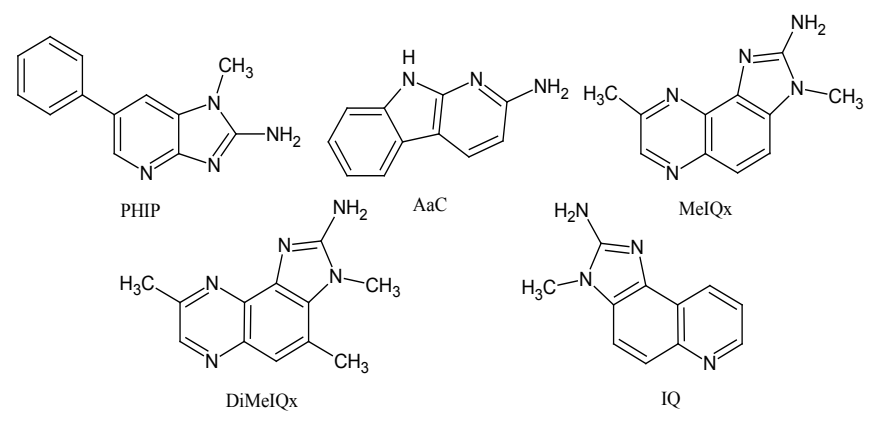

Figure 6: Structures of some heterocyclic aromatic amines. 
carcinogens than originally anticipated from the animal experiments. However, tumor promoting effects have not been calculated so far [53], but could play a more decisive role in determining the carcinogenicity of HAAs than thought up till now. Existing epidemiologic evidence is suggestive for a causative connection between high meat consumption, HAAs, and colon cancer [57]. Moreover, available epidemiologic evidence is exceptionally strong and consistent between consumption of high levels of fruits and vegetables and a reduced risk of cancer at most sites, particularly epithelial cancers of the alimentary and respiratory tract [59]. Knowledge about anticarcinogenic agents in fruits and vegetables is limited [60,61], as well as knowledge about the various protective mechanisms of action of phytochemicals. The balance, however, between harmful and protective mechanims should be decisive for the final outcome of the disease. Since effects at the initial stage of the carcinogenic process correlate well with the known strong mutagenic properties of most HAAs, Salmonella/reversion assay in previous studies had been used as a model system to check fruits and vegetables for the presence of antimutagenic activities, as well as for the effects of compounds of known structure such as anthraquinones, flavonoids, coumarins and other phytochemicals [62].

Since the activation of these heterocyclic aromatic amines is catalyzed by the cytochrome P450 (CYP) 1A family, 1A1, and 1A2 [63], so the inhibition of N-hydroxylation activity of CYP1A1 is essential for the antimutagenicity toward Trp-P-2. Sun et al. [28] reported the antimutagenicity of 10 commercial AQs (Table 1, Compounds 1, 2, 1417, 25-27 and 29), against Trp-P-2 and revealed that, almost all tested anthraquinones were active as antimutagens in a dose-dependent manner without any noticeable cytotoxicity, e.g., anthraquinone itself was the most potent antimutagen than others, its antimutagenicity retained by the introduction of 1,4-dihydroxy and/or 1,3,8-trihydroxy6-methyl functions (14 and 29) respectively, moreover, the polar function as $\mathrm{COOH}$ at $\mathrm{C}-3$ (26) decreased the activity. Furthermore, the antimutagenic activity of anthraquinones was compared to their inhibition toward N-hydroxylation of CYP1A1, all the tested AQs except anthraquinone itself, exhibited $\mathrm{IC}_{50}$ values ranging from $0.29-21$ $\mu \mathrm{M}$ for antimutagenicity and similar values for CYP inhibition. Since metabolic activation by CYP is a primary step in the genotoxicityproducing process [62], similarity in both $\mathrm{IC}_{50}$ values indicates that the antimutagenicity of AQs was attributable to inhibition of the N-hydroxylation of Trp-p2 by CYP1A1. Moreover, Edenharder et al. [62] demonstrated a distinct study of SAR of 19 anthraquinones (Table 1, Compounds 2, 14-18 and 25-38), that inhibited mutagenicity induced by (IQ) in Salmonella typhimurium TA 98 in the presence of rat liver S9. From this study it can be concluded that, in general, AQs were potent antimutagens with the presences of a carbonyl function as a prerequisite for antimutagenicity. The parent compound (2) and its methyl substituted derivatives were already the most potent, while the introduction of polar substituents such as $\mathrm{COOH}$ and $\mathrm{SO}_{3} \mathrm{H}$ considerably reduced the antimutagenicity. Introduction of $\mathrm{OH}$ functions had equivocal effects: with increasing numbers, antimutagenic potencies were concomitantly reduced; however, anthraflavic acid, chrysazin and quinizarin were more potent than the parent compounds, this comes in accordance with the fact that the number of hydroxyl groups is less effective than their exact positions.

These results imply that the overall size of the anthraquinone molecule (planarity) is an important determinant of antimutagenic potency. This can be illustrated clearly as follow; anthraquinone, tectoquinone, quinizarin, chrysazin and anthraflavic acid were the most potent. Alizarin was somewhat less effective, while anthrarufin and 2-hydroxymethyl-anthraquinone were distinctly less potent. In general, additional $\mathrm{OH}$ (i.e., purpurin, emodin) or $\mathrm{CH}_{2} \mathrm{OH}$ functions (aloe-emodin) further reduced antimutagenicity, while introduction of strong polar substituents such as $\mathrm{COOH}$ or $\mathrm{SO}_{3} \mathrm{H}$ considerably diminished antimutagenicity (26 and 31-33). No influence of a methyl group at C-2 could be detected, whereas a methyl group at C-3 (27) seems to reduce antimutagenic potency. Reduction of polarity by methylation of the 6-OH of emodin (30) did not change much. On the other hand, the presence of a glycosidic function at C-3 (37 and 38) reduces antimutagenicity only by about $30 \%$ as compared with emodin [62].

Most effects observed can easily be explained by considering that expression of mutagenicity of IQ comprises two major steps of metabolic activation: hydroxylation of IQ to $\mathrm{N}-\mathrm{OH}-\mathrm{IQ}$ and esterification reactions of $\mathrm{N}-\mathrm{OH}-\mathrm{IQ}$ to generate the ultimate mutagenic metabolite. Hydroxylation of IQ monitored by measurement of MROD (7-methoxyresorufin-O-demethylase) and EROD (7-ethoxyresorufin$O$-deethylase) activities in rat liver microsomes was inhibited with similar efficiency by AQs (i.e., alizarin and anthraflavic acid). With respect to these anthraquinones, inhibition of mutagenic activity induced by IQ in $S$. typhimurium might be caused exclusively by inhibition of cytochrome P-450-dependent mono-oxygenases 1A1 and $1 \mathrm{~A} 2$ [63]. By comparing the above test and the Salmonellal reversion assay, it can be concluded that, the presence of methyl functions i.e., chrysophanic acid and emodin is obviously the reason for the high inhibitory potency against MROD and EROD activities. On the other hand, the reasons for the lower $\mathrm{IC}_{50}$ values of most other anthraquinone derivatives are unknown. Nevertheless, there is an agreement that anthraquinone, chrysazin and quinizarin are the most potent quinones, that there is a good correlation between inhibition of ECD (7-ethoxycoumarin-O-deethylase), MROD and EROD activities, and IQ induced mutagenesis for many compounds, and that inhibition of cytochrome P-450-dependent mono-oxygenases is a major determinant of antimutagenicity of anthraquinones against IQ [62].

SAR studies of AQs with respect to N-OH-IQ induced mutagenesis in S. typhimurium TA $98 \mathrm{NR}$ might also play a role in this context. Di- and trihydroxyanthraquinones were effective inhibitors with $\mathrm{ID}_{50}$ values about 10 to 20 -fold higher than in the case of IQ, while the parent compound was inactive as well as derivatives with $\mathrm{COOH}$ and $\mathrm{SO}_{3} \mathrm{H}$ functions, chrysophanic acid and emodin. The methyl substituted derivatives 2,3-dimethylquinizarin, 2-hydroxymethylanthraquinone and tectoquinone even exerted comutagenic effects. The reasons are unknown but stimulation of enzymes activating $\mathrm{N}-\mathrm{OH}$ IQ, intercalation with the DNA and formation of new compounds by enzymes of the $\mathrm{S} 9 \mathrm{mix}$ are among the conceivable possibilities. On the other hand, the antimutagenicity enhancing effect of hydroxyl groups, especially in certain positions of the nucleus, may be caused by intramolecular hydrogen bonding [36], subsequent oxidation to quinones (with higher hydrogen bonding potency), and finally direct interaction with N-OH-IQ [63].

In a theoretical study by Lewis et al. [65], based on molecular orbital calculations and molecular graphics, structural requirements for hydroxylation of xenobiotica by cytochrome P-450-dependent mono-oxygenases were outlined. Substrates with fused aromatic or heteroaromatic rings such as benzo $[\alpha]$ pyrene $(\mathrm{BaP})$ and IQ gave rise to overall molecular planarity with relatively small molecular depth. The binding sites of these isozymes therefore must contain hydrophobic aromatic amino acid residues, but do contain also hydrophilic amino acid residues capable of hydrogen bonding to carbonyl moieties of the anthraquinone molecule [64]. This could be an explanation for the fact that anthraquinone with its two carbonyl functions 'though named quinone it is in fact a diketonic compound' was the most potent inhibitor of MROD/EROD and ECD activities. As demonstrated above, 
mutagenicity induced by IQ, as well as MeIQx, Glu-P-1 and Trp-P-2, in S. typhimurium TA 98 was effectively inhibited by chrysazin, chrysophanic acid, physicon and purpurin. Antimutagenic effects of anthraquinone derivatives, as well as of various quinoidic aromatic compounds against mutagenicity induced by HAAs and other mutagens in S. typhimurium were also observed by other investigators. Among these AQs; aloe-emodin, chrysophanol, emodin and physicon were active against Trp-P-1, Trp-P-2 and other HAAs [50], various anthraquinone derivatives were active against the ultimate mutagenic metabolite of BaP. The 7,8-diol-9,10-epoxide of anthraflavic acid showed activity against IQ [65], while emodin was active against IQ, Trp-P-2, and $\mathrm{BaP}$ of tanshinones. Tetracyclic heterocyclic quinones isolated from the radix of Salvia miltiorrhiza revealed activity against Trp-P-1 and $\mathrm{BaP}$ [51]. The quinoidic metabolites of butylated hydroxyanisole were active against Trp-P-2 [66]. Moreover, 1-O-hexyl-2,3,5-trimethylhydroquinone and derivatives with other alkyl substituents were active against eight HAAs $[67,68]$.

Taken the above considerations together one may conclude that all quinones which meet the criteria established by Lewis et al. [65] may be effective inhibitors of polycyclic and heteroaromatic mutagens in S. typhimurium. Inhibition of P-450-dependent mono-oxygenases by quinones was demonstrated in several studies with subcellular liver fractions in vitro. Lipophilic quinones were in general more effective inhibitors than their more polar derivatives and it can be anticipated that the former compounds easily penetrate the plasma membrane of mammalian cells, e.g., liver parenchyma cells, thereby inhibiting mono-oxygenases as well. The degree of enzyme inhibition and consequently the antimutagenic effect of quinones in vivo obviously will depend on the amount of these compounds in food as well as on their bioavailability. Among natural quinones, vitamin K1 participates in the photosynthetic process and is therefore present in all green plants. Among edible plants, particularly high concentrations are present in cruciferous vegetables, green salads and spinach, while low concentrations were found in other vegetables and fruits. As shown previously, antimutagenic and possibly anticarcinogenic effects may be exerted in the mammal and possibly also in the human besides the wellknown antihemorrhagic function. AQs may be found in Hyperiaceae, Polygonaceae, Rhamnaceae and Rubiaceae, but aside from rhubarb, sorrel and possibly Cassia, none of these plants could be considered edible [69]. However, hydroxyanthraquinones are the active principles of many phytotherapeutic drugs, among which laxatives are most important.

\section{Anti-mutagenicity of anthraquinones against dioxins}

Environmental contaminants, e.g., dioxins, develop various adverse effects through transformation of a cytosolic aryl hydrocarbon receptor (AhR), which is a sequential action of ligand binding to the $\mathrm{AhR}$, translocation of the receptor into the nucleus, binding of AhR/ ARNT to the DRE-site on DNA, and transactivation of AhR/DREdriven genes [70,71]. Because dioxins invade the body mainly with diets, it is important to search for antagonistic compounds from natural sources. Flavonoids, lutein, resveratrol, curcumin and theaflavins were reported [72-76] as antagonists of the AhR, suggesting that pigments (e.g., anthraquinones) including polyphenols are good candidates for the AhR antagonists. AQs are reported to have antimutagenic activity by inhibiting CYP1A1, which is a downstream of the AhR, and this inhibition requires three rings with an oxygen function in the side ring [28]. A hypothesis arisen from these results that the suppressive effects of AQs on the AhR require the same affinity region as that CYP do, which is consistent with the previous report demonstrating that the structures required for the suppression of AhR transformation are the same fashion as that for the suppression of CYP1A1 [71,77].
Fukuda et al. [75] investigated the effects of 18 anthraquinone (Table 1, Compounds 2 and 14-30) on the transformation of the AhR estimated by its DNA-binding activity in the cell-free system, induced by $1 n \mathrm{M}$ 2,3,7,8-tetrachlorodibenzo-p-dioxin (TCDD). The obtained results revealed that; quinizarin, anthrarufin and danthron strongly suppressed DNA-binding activity of the $\mathrm{AhR}$, with their $\mathrm{IC}_{50}$ values around $1 \mu \mathrm{M}$, while anthraquinone and anthraflavic acid showed moderate effects. QSAR analysis demonstrated that hydroxyl groups at $\mathrm{C}-1,-4,-5$, or -8 of anthraquinone structure are important to reveal the suppressive effects on AhR transformation. Indeed, hydroxyl groups at C-1 or C- 4 but not C-3 positions of the structure are critical for the suppressive effects and consequently antimutagenic activity. In addition, all compounds had no agonistic effect. The suppressive effects of AQs in a cultured cell system were also confirmed, in human hepatoma HepG2 cells; chrysophanol, danthron and rhein also suppressed the DNA-binding activity in a dose-dependent manner, although aloe-emodin showed a moderate effect, these findings may be useful for the design of novel antagonists of the AhR. Kuo et al. [78] investigated the SAR of AQs on intestinal motility using rabbit small intestinal strips. This study revealed the critical requirement of a hydroxy group at C-2 position, whereas the presence of other polar groups at this position, such as an amino, aldehyde and carboxylic acid significantly reduced the activity. The presence of a methyl group and esterification of the carboxylic acid at C-2 was found to abolish the activity.

Amakura et al. [79] demonstrated that three AQs; emodin, aloe-emodin and alizarin suppressed $5 n \mathrm{M}$ TCDD-induced AhR transformation, but the concentration of TCDD is extremely higher than that in the physiological level, and the structure-activity relationship in the suppressive effects has not been clear yet, while the suppressive effects of anthraquinones on DNA-binding activity of the AhR were examined in both cell-free and cultured cell systems [77]. Interestingly, the suppressive effects of danthron and rhein against higher concentrations of TCDD were dramatically different; the $\mathrm{IC}_{50}$ values of danthron retained around $1-2 \mu \mathrm{M}$, while that of rhein changed from 3.9 to $66.7 \mu \mathrm{M}$, this may be due to the additional $\mathrm{COOH}$ group at $\mathrm{C}-3$ position which can be accounted for this change. AQs which have the basic structure of danthron with a functional group at C-3 (i.e., chrysophanol and aloe-emodin) had higher $\mathrm{IC}_{50}$ values than danthron, suggesting that hydrophobicity is important to the interaction with the AhR complex or ligand binding pocket of the AhR. However, anthraquinone, which has the basic structure, did not suppress AhR transformation, indicating that only hydrophobicity is not critical for the suppressive effects. GA-PLS analysis indicated that structure parameters and the positions of hydroxyl groups are important for the suppressive effects, and further study is needed for the other functional groups contributing to the suppressive effects in the future. Quinizarin and anthrarufin also showed suppressive effects with the $\mathrm{IC}_{50}$ values close to that of danthron. It is, therefore, suggested that AQs which have $\mathrm{OH}$ groups at $\mathrm{C}-1$ or $\mathrm{C}-4$ positions, suppress $\mathrm{AhR}$ transformation by interacting with the receptor protein or its partner proteins.

The preliminary data demonstrated that danthron and rhein inhibited the specific binding between agonists and the AhR, suggesting that anthraquinones suppress AhR transformation by inhibiting agonist binding to the AhR. The absorption and metabolism of anthraquinone laxatives has been well studied. Chrysophanol is transformed into aloe-emodin by CYP-dependent oxidation $[80,81]$, and aloe-emodin is quickly metabolized to rhein in rats [82]. The metabolism and recovery rates of major anthraquinones are demonstrated by using their ${ }^{14} \mathrm{C}$-labelled compounds, and the large amounts of anthraquinones are excreted to urine [83], indicating that anthraquinones are absorbed 
through intestinal cells and metabolized in hepatocytes, and finally excreted. In the cultured cell system, chrysophanol, danthron, and rhein doses dependently suppressed DNA-binding activity of the AhR, while aloe-emodin showed a moderate effect. In the cell-free system, the order of the suppressive effects ranked as follows; danthron $>$ rhein $>$ aloeemodin $>$ chrysophanol. Danthron has the basic structure of these four compounds, and clearly suppressed the DNA-binding activity of the AhR not only in the cell-free system but also in the cultured cell system. The differences of the suppressive effects in the cell-free and cultured cell systems might be due to absorption rate of anthraquinones and/or metabolization in hepatocytes in addition to the affinity to ligand binding pocket of the AhR. Because the affinity of ligands to the AhR is reported as different among species, the difference between rat and human in the cell-free and cultured cell systems might be also a cause of the disparate results [84]. In conclusion, anthraquinones have antimutagenic activity by its ability to reduce dioxin toxicity through suppression of AhR binding to DRE site with the structure-activity relationship.

\section{Mutagenic activity}

Many natural and synthetic hydroxy-, amino-, nitro- and benzAQs are mutagenic in the Ames/Salmonella assay $[69,85,86]$. The majority of these AQs are classified as frameshift mutagens (those cause insertion or deletions of a number of nucleotides in a DNA sequence) due to their reactivity toward Ames strains TA1537, TA1538 or TA98. Liberman et al. [86] reported that chrysophanol and islanding mycotoxins (Table 1, Compounds 27 and 45) produced by Penicillium islandicum are frameshift mutagens which require metabolic activation (S9). The mutagenic activity associated with these two mycotoxins is quantitatively different from that observed with emodin, a known mutagenic mycotoxin for TA1537 [85].

Lieberman et al. [87] studied the structure-mutagenic activity relationships for these three mycotoxins (chrysophanol, islandicin and emodin), and concluded that chrysophanol might represent the basic mutagenic structure. Furthermore, the presence of an oxygen moiety at position 10 and/or a methyl group at C-3 may play part of the mutagenic site, and that the quantitative differences in mutagenic activity between chrysophanol, islandicin, and emodin were due to the position of the additional $\mathrm{OH}$ group found in emodin and islandicin. Placement of this $\mathrm{OH}$ group at C-6 (emodin) facilitated, or at C-4 (islandicin) restricted, either the interaction with DNA or the activation to the mutagenic species by rat liver homogenate [87]. As it is appeared previously, that, there are reports on the genotoxic and evidences on the tumorigenic potentials of anthraquinones and/or their glycosides in mice and rats, i.e., the anthraquinones glycosides isolated from senna and cascara were believed to behave as a weak promotors in rat colon carcinogenesis [88]. Furthermore, toxicological studies carried out on hydroxyanthraquinones (i.e., aloe-emodin and emodin) present as minor components in senna, suggested that they may represent a genotoxic or cancerogenetic risk for man [89]. Mueller et al. [90] investigated the genotoxicity of 1,2-dihydroxyanthraquinones present in Chinese herbs and the mutation assay in lymphoma L5178Y, and observed that, emodin was genotoxic whereas chrysophanol and physcion showed no effects. Moreover, Mueller et al. [90,81] had reported that plant derived 1,8-dihydroxyanthraquinone derivatives i.e., emodin and danthron were clearly genotoxic in mouse lymphoma L5178Y cells, whereas chrysophanol was only weakly genotoxic and physcion not at all. These studies suggested that these compounds bound non-covalently to DNA and inhibited topoisomerase II activity. This comes in accordance with the understanding that the genotoxicity of anthraquinones is, at least in part, mediated by noncovalent DNA-binding. Other investigations stated that, the genotoxicity and mutagenicity of anthraquinones are mainly due to the inhibition of the catalytic activity of topoisomerase II $[91,92]$. Furthermore, recent studies suggested that cytochrome P450 involves biotransformation of emodin and chrysophanol through bioactivation pathways $[80,81,93,94]$. Additionally, Tanaka et al. [95] reported that 1-hydroxyanthraquinones isolated from Rubia tinctorurn L. (madder root) are genotoxic agents and mice colon carcinogens. Lucidin was shown to be responsible for the potential genotoxic activity of madder root extracts. It suggested that the presence of two hydroxy groups in the 1,3-positions is a structural requirement for the genotoxicity of hydroxyanthraquinones such as lucidin [96].

Other investigations showed the ability of AQs in promoting other neoplastic lesions such as skin tumor and cutaneous melanoma in mice $[97,98]$ and on the bone marrow cells of mice [99]. Several benzo- and naphthoquinones have also been shown to be oxidative mutagens [100]. More recently, Guerra et al. [101] have investigated the teratogenic potential of lapachol, a naphthoquinone with therapeutic potential. Results have shown a strong abortifacient effect of lapachol in rats.

\section{Absorption of anthraquinones}

Orally administration of anthraquinones revealed that, anthraquinone glycosides are poorly absorbed than its aglycones, they are inactive in the gastrointestinal tract until they reach the colon, where they hydrolysed by colonic bacteria and absorbed moderately. Finally they are partially eliminated renally, in feces, and in bile [102]. Subchronic or prechronic exposure of laboratory animals to anthraquinones revealed no death at a dose of $2,10,20,50$ or $250 \mathrm{mg} / \mathrm{kg}$ bw/day and no toxicity was observed at $2 \mathrm{mg} / \mathrm{kg}$ bw/ day of anthraquinone, observations also showed body weight loss, lowered level of haemoglobin, and increased liver weight (For more details, please visit https://toxnet.nlm.nih.gov/cgi-bin/sis/search/ a?dbs+hsdb:@term+@DOCNO+2074).

\section{Conclusion}

From the presented study, we can conclude that the number of hydroxyl substituents of AQs seems to be less influential on the antimutagenicity rather than their exact positions. As confirmed by SAR study that $\mathrm{OH}$ at C-3 may play an important role for their cytotoxicities, while $\mathrm{OH}$ or $\mathrm{OCH}_{3}$ groups at C-3 is necessary for the antimutagenicity, even though the importance of $\mathrm{OH}$ groups at C-1 and C-8 positions. However, substitution of $\mathrm{OH}$ with $\mathrm{OCH}_{3}$ at C-1 increases the inhibition of the enzymatic activity of the Cdc25B phosphatase and hence increases their cytotoxicity. SAR studies of AQs against nitroarenes concluded that as the polarity of the AQs increased their antimutagenicity increased. While, the SAR studies of AQs against heterocyclic aromatic amines mutagenicity, and QSAR analysis of AQs against dioxins, demonstrated that as the polarity of the AQs decreased their antimutagenicity increased against heterocyclic aromatic amines and dioxins, which suggests the same mechanism of action.

The overall conclusion of the structure-antimutagenic activity relationships of AQs are; the planarity of the anthraquinone molecule, antimutagenicity was widely linked to aglycones, the presence of 1,8-dihydroxy groups is optimal and finally the introduction of a nonpolar substituent at C-3 may enhance the activity, while polar groups at the same position abolish the activity. The antimutagenicity of the AQs may enhanced by the synergistic effect of AQs, especially those have the structure requirements for the activity. SAR studies suggested that, the inhibitory action on CYP1A1 enzyme which is a downstream of the AhR, required three aromatic rings (planarity) and an oxygen group in the side ring (hydrophobicity), which constructed a region of interaction with the CYP enzyme (Figure 7). 
<smiles>[R]c1cc(O)c2c(c1)C(=O)c1cc(Br)cc(O)c1C2=O</smiles>

Figure 7: The affinity regions of hydrophobic and coplaner anthraquinones for interacting with CYP1A1.

\section{References}

1. Hartl DL, Davis RH, Weller SJ (1994) Study Guide for Genetics. 3rd edn. Jones and Barlett Publishers, New York, USA.

2. Douglas BM (1987) Genotoxic Chemicals in the Human Environment; Their Identification and Interaction.

3. De Flora S, Izzotti A, Randerath K, Randerath E, Bartsch H, et al. (1996) DNA adducts and chronic degenerative disease. Pathogenetic relevance and implications in preventive medicine Mutat Res 366: 197-238.

4. Prabhu N, Elizabath GS, Joice PA, Soumya TS (2010) Effect of Rosa multiflora extract on chemical mutagens using Ames assay Der Pharma Chem 2: 91-97.

5. Mitscher LA, Drak S, Gollapuri SR, Harris JA, Shankel DM (1986) Antimutagenesis and Anticarcinogenesis Mechanisms. Plenum Press, New York, USA

6. Bronzetti G (1994) Antimutagens in food; Trends Food Sci and Technol 5: 390-395

7. Kada T, Inoue T, Namiki M (1982) Environmental Mutagenesis, Carcinogenesis and Plant Biology. New York, pp: 135-151.

8. De Flora S, Izzotti A, Benniceili C (1992) Mechanisms of Anti-mutagenesis and Anti-carcinogenesis, Role in Primary Protection, New York 61: 162-178.

9. Musarrat J, Aqil F, Ahmad I (2006) Mutagenicity and Anti-mutagenicity of Medicinal Plants: 271-291.

10. Middleton JRE, Kandaswami C (1993) Plant Flavonoid Modulation of Immune and Inflammatory Cell Functions: Nutrition and Immunology, New York, pp: 239-266.

11. Stewart BW, Kleihues P (2003) World Cancer Report. WHO Lyon.

12. Crowell PL (1999) Prevention and therapy of cancer by dietary monoterpenes. J Nutr 129: 775S-778S

13. Paduch R, Kandefer-Szersze M, Trytek M, Fiedurek J (2007) Terpenes: substances useful in human healthcare. Arch Immunol Ther Exp (Warsz) 55 315-327.

14. Bakkali F, Averbeck S, Averbeck D, Idaomar M (2008) Biological effects of essential oils: a review Food Chem Toxicol 46: 446-475.

15. Jyothsna K, Geetha M (2013) Protective measures of vitamin C extract on cisplatin-induced cytogenotoxicity in human lymphocytes in vitro; J Bio Innovation 2: 152-160.

16. Mathis C (1966) Comparative Biochemistry of Hydroxyquinones. New York, USA.

17. Seigler DS (1998) Plant Secondary Metabolism. Kluwer Academic Pub, New York, pp: 76-93.

18. Tiwari RD, Singh J (1979) A new anthraquinone digalactoside from Cassia laevigata pods. Pergamon press Ltd., England 18: 347.

19. Luckner M (1984) Secondary Metabolism in Microorganisms. Plants and Animals, p: 181

20. Packter NM (1980) Biosynthesis of acetate-derived phenols (polyketides). In Lipids Structure and Function, Stumpf PK (ed), New York, USA 4: 535-570.

21. Ellis BE (1988) Natural products from plant tissue culture. Nat Prod Rep 5: $581-612$

22. Dahlgren RMT, Rosendal Jensen S, Nielsen BJ (2003) A revised classification of the angiosperms with comments on correlation between chemical and other characters. Praeger, New York 198: 149-204.

23. Ames $B N$ (1979) Identifying environmental chemicals causing mutations and cancer Science 204: 587-593.
24. Shankel DM, Pillai SP, Telikepalli $H$, Menon SR, Pillai CA, et al. (2000) Role of antimutagens/anticarcinogens in cancer prevention. Biofactors 12: 113-121.

25. Kamei H, Koide T, Kojima T, Hashimoto Y, Hasegawa M (1998) Inhibition of cell growth in culture by quinones. Cancer Biother Radiopharm 13: 185-188.

26. Ali AM, Ismail NH, Mackeen MM, Yazan LS, Mohamed SM, et al. (2000) Antiviral, cytotoxic and antimicrobial activities of anthraquinone isolated from the roots of Morinda elliptica: Pharmaceut Biol 38: 298-301.

27. Lee HZ, Hsu SL, Liu MC, Wu CH (2001) Effects and mechanisms of aloeemodin on cell death in human lung squamous cell carcinoma. Eur J Pharmaco 431: 287-295.

28. Sun M, Sakakibara H, Ashida H, Danno G, Kanazawa K (2000) Cytochrome P4501A1-inhibitory action of antimutagenic anthraquinone activity relationship: Biosci Biotech Biochem 64: 1373-1378.

29. Kuo YC, Tsai WJ, Meng HC, Chen WP, Yang LY, et al. (2001) Immune reponses in human mesangial cells regulated by emodin from Polygonum hypoleucum Ohwi Life Sci 68: 1271-1286.

30. Pecere T, Gazzola MV, Mucignat C, Parolin C, Dalla Vecchia F, et al. (2000) Aloe-emodin is a new type of anticancer agent with selective activity agains neuroectodermal tumors Cancer Res 60: 2800-2804.

31. Wasserman L, Avigad S, Beery E, Nordenberg J, Fenig E (2002) The effect of aloe emodin on the proliferation of a new merkel carcinoma cell line Am J Dermatopathol 24: 17-22.

32. Grimaudo S, Tolomeo M, Gancitano RA, Alessandro ND, Aiello E (1997) Effects of highly purified anthraquinoids compounds from Aloe vera $L$ on sensitive and multidrug resistant leukemia cells Oncol Reports 4: 341-343.

33. Shimpo K, Chihara T, Beppu H, Ida C, Kaneko T, et al. (2001) Inhibition of azoxymethane-induced aberrant crypt foci formation in rat colorectum by whole leaf Aloe arborescens Miller var. natalensis Berger Phytother Res 15: 705-711.

34. Fahim FA, Esmat AY, Mady EA, Amin MA (1997) Pharmacokinetic and tumor studies of aloin (a natural anthraquinone) on mice bearing solid Ehrlich carcinoma: J Tumour Marker Oncol 12:127-134.

35. Fahim FA, Esmat AY, Mady EA, Amin MA (1997) Serum LDH and ALP isozyme activities in mice bearing solid Ehrlich carcinoma and/or treated with the maximum tolerated dose (MTD) of aloin. Dis Markers 13: 183-193.

36. Metenawy WH, Esmat AY (1996) Cytotoxicity of a natural anthraquinone (Aloin) against breast and ovarian tumour cell lines in comparison to conventional chemotherapeutic drugs. Cancer Mol. Biol. 3: 851-864.

37. Mohammed MMD, El Souda SS, El Hallouty SM, Kobayashi N (2013) Antiviral and cytotoxic activities of anthraquinone isolated from Cassia roxburghii Linn Leaves. Herba Polonica 59: 33-44.

38. Lee NJ, Choi JH, Koo BS, Ryu SY, Han YH, et al. (2005) Antimutagenicity and cytotoxicity of the constituents from the aerial parts of Rumex acetosa. Bio Pharm Bull 28: 2158-2161.

39. Lyon MA, Ducruet AP, Wipf P, Lazo JS (2002) Dual-specificity phosphatases as targets for antineoplastic agents. Nat Rev Drug Discov 1: 961-976.

40. Choi SG, Kim J, Sung ND, Son KH, Cheon HG, et al. (2007) Anthraquinones Cdc25B phosphatase inhibitors, isolated from the roots of Polygonum multiflorum Thunb. Nat Prod Res 21: 487-493.

41. IARC (1989) IARC Monographs on the evaluation of carcinogenic risks to humans. Diesel and gasoline engine exhausts and some nitroarenes Lyon: 46

42. Pitts JN, van Cauwenberghe KA, Grosjean D, Schmid JP, Fitz DR, et al. (1978) Atmospheric reactions of polycyclic aromatic hydrocarbons: facile formation of mutagenic nitro derivatives Sci 202: 515-519.

43. Rosenkranz HS, Mermelstein R (1985) The genotoxicity, metabolism and carcinogenicity of nitrated polycyclic aromatic hydrocarbons: J Environ Sci Health 3: 221-272.

44. Dennis MJ, Massey RC, McWeeny DJ, Knowles ME (1984) Estimation of nitropolycyclic aromatic hydrocarbons in foods. Food Addit Contam 1: 29-37.

45. Ohnishi Y, Kinouchi T, Tsutsui H, Uejima M, Nishifuji K (1986) Mutagenic Nitropyrenes in Foods. Proceedings of the International Symposium Princess Takamatsu Cancer Research Fund 16th. Diet, Nutrition, Cancer, pp: 107-118.

46. Hirose M, Wakabayashi K, Gtivas S, De Flora S, Arakawa N, et al. (1990) Formation of a nitro derivative of 2-amino-3,4-dimethylimidazo[4,5-f]quinoline by photo-irradiation, Carcinogenesis 11: 869-871. 
47. Horikawa K, Sera N, Otofuji T, Murakami K, Tokiwa H, et al. (1991) Pulmonary carcinogenicity of 3,9- and 3,7-dinitrofluoranthene, 3-nitrofluoranthene and benzo[a]pyrene in F344 rats. Carcinogenesis 12: 1003-1007.

48. El-Bayoumy K (1992) Environmental carcinogens that may be involved in human breast cancer etiology. Chem Res Toxicol 5: 585-590.

49. Möller L, Lax I, Torndal UB, Eriksson LC (1993) Risk assessment of nitrated polycyclic aromatic hydrocarbons, Risk Anal 13: 291-299.

50. Edenharder R, Tang X (1997) Inhibition of the mutagenicity of 2-nitrofluorene, 3-nitro-fluoranthene and 1-nitrtopyrene by flavonoids, coumarin, quinones and other phenolic compounds, Food Chem Toxicol 35: 357-372.

51. Su HY, Cherng SH, Chen CC, Lee H (1995) Emodin inhibits the mutagenicity and DNA adducts induced by 1-nitropyrene. Mutat Res 329: 205-212.

52. Kushi K, Koiwai A, Yoshida D, Goto F (1980) Effect of emodin on the mutagenicity of 3-amino-1-methyl-5H-pyrido[4,3-ß]indol toward Salmonella. Agric Biol Chem 44: 2513-2515.

53. Sato M, Sato T, Ose $Y$, Nagase $H$, Kito $H$, et al. (1992) Modulating effect of tanshinones on mutagenic activity of Trp-P-1 and benzo[a]pyrene in Salmonella typhimurium Mutat Res 265: 149-154.

54. Layton DW, Bogen KT, Knize MG, Hatch FT, Johnson VM, et al. (1995) Cance risk of heterocyclic amines in cooked foods. an analysis and implications for research: Carcinogenesis 16: 39-52.

55. Ohgaki H, Takayama S, Sugimura T (1991) Carcinogenicities of heterocyclic amines in cooked food. Mutat Res 259: 399-410.

56. [No authors listed] (1986) Some naturally occurring and synthetic food components, furocoumarins and ultraviolet radiation. IARC Working Group Lyon. IARC Monogr Eval Carcinog Risk Chem Hum 40: 1-415.

57. Skog K (1993) Cooking procedures and food mutagens: a literature review. Food Chem Toxicol 31: 655-675.

58. Hatch FT, Knize MG, Moore DH, Felton JS (1992) Quantitative correlation of mutagenic and carcinogenic potencies for heterocyclic amines from cooked foods and additional aromatic amines Mutat Res. 271: 269-287.

59. Block G, Patterson B, Subar A (1992) Fruit, vegetables, and cancer prevention: A review of the epidemiological evidence Nutrition Cancer 18: 1-29.

60. Hartman PE, Shankel DM (1990) Antimutagens and anti-carcinogens: a survey of putative interceptor molecules. Environ Mol Mutagen 15: 145-182.

61. Hayatsu H, Arimoto S, Negishi T (1988) Dietary inhibitors of mutagenesis and carcinogenesis. Mutat Res 202: 429-446.

62. Edenharder R, Speth C, Decker M, Platt KL (1998) The inhibition by naphthoquinones and anthraquinone of 2-amino-3-methylimidazo [4,5-f?] quinolone metabolic activation to a mutagen: a structure-activity relationship study. Und-Forsch. 207: 464-547.

63. Funae Y, Imaoka S (1993) Cytochrome P450 in Rodents. Handbook of experimental pharmacology 105: 221-238.

64. Hao NJ, Huang MP, Lee H (1995) Structure-activity relationships of anthraquinones as inhibitors of 7-ethoxycoumarin O-deethylase and mutagenicity of 2-amino-3methylimidazo[4,5-f] quinoline. Mutat Res 328: 183-191.

65. Lewis DF, loannides C, Parke DV (1987) Structural requirements for substrates of cytochromes P-450 and P-448. Chem Biol Interact 64: 39-60.

66. Ayrton AD, loannides C, Walker R (1988) Anthraflavic acid inhibits the mutagenicity of the food mutagen IQ: mechanism of action. Mutat Res 207: $121-125$

67. Mizuno M, Toda M, Ueno N, Danno G, Kanazawa K, et al. (1989) Desmutagenicity of a dibenzofuran-quinone derivative toward the mutagenicity of Trp-P-2. Agric Bio Chem 53: 959-964.

68. Hirose M, Iwata S, Ito E, Nihro Y, Takahashi S (1995) Strong anti-mutagenic activity of the novel lipophilic antioxidant 1-O-hexyl-2,3,5-trimethylhydroquinone against heterocyclic amine-induced mutagenesis in the Ames assay and its effect on metabolic activation of 2-amino-6-methyldipyrido[,2-a:3',2'-d]imidazole (Glu-P-1). Carcinogenesis 16: 2227-2232.

69. Brown JP (1980)A review of the genetic effects of naturally occurring flavonoids, anthraquinones and related compounds. Mutat Res 75: 243-277.

70. Whitlock JP Jr (1993) Mechanistic aspects of dioxin action. Chem Res Toxico 6: 745-763.
71. Hankinson O (1995) The aryl hydrocarbon receptor complex. Annu Rev Pharmacol Toxicol 35: 307-340

72. Ashida H, Fukuda I, Yamashita T, Kanazawa K (2000) Flavones and flavonols at dietary levels inhibit a transformation of aryl hydrocarbon receptor induced by dioxin. FEBS Lett 476: 213-217.

73. Ciolino HP, Yeh GC (1999) Inhibition of aryl hydrocarbon-induced cytochrome $\mathrm{P}-450$ 1A1 enzyme activity and CYP1A1 expression by resveratrol. Mol Pharmacol 56: 760-767.

74. Ciolino HP, Daschner PJ, Wang TT, Yeh GC (1998) Effect of curcumin on the aryl hydrocarbon receptor and cytochrome P450 1A1 in MCF-7 human breast carcinoma cells. Biochem Pharmacol 56: 197-206.

75. Fukuda I, Sakane I, Yabushita Y, Kodoi R, Nishiumi S, et al. (2004) Pigments in green tea leaves (Camellia sinensis) suppress transformation of the aryl hydrocarbon receptor induced by dioxin. J Agric Food Chem 52: 2499-2506.

76. Fukuda I, Sakane I, Yabushita Y, Sawamura S, Kanazawa K, et al. (2005) Black tea theaflavins suppress dioxin-induced transformation of the aryl hydrocarbon receptor Biosci Biotech Biochem 69: 883-890.

77. Fukuda I, Kaneko A, Nishiumi S, Kawase M, Nishikiori R (2009) Structureactivity relationships of anthraquinone on the suppression of DNA-binding activity of the aryl hydrocarbon receptor induced by 2,3,7,8-tetrachlorodibenzop-dioxin. J Biosci Bioengineering 107: 296-300.

78. Kuo DH, Kuo SC, Cheng JT (2000) Structure-activity relationships of anthraquinones in the decrease of intestinal motility. J Pharm Pharmacol 52: 839-841.

79. Amakura Y, Tsutsumi T, Sasaki K, Yoshida T, Maitani T (2003) Screening of the inhibitory effect of vegetable constituents on the aryl hydrocarbon receptor mediated activity induced by 2,3,7,8-tetrachlorodibenzo-p-dioxin: Bio Pharm Bull 26: 1754-1760.

80. Mueller SO, Stopper H, Dekant W (1998) Biotransformation of the anthraquinones emodin and chrysophanol by cytochrome P450 enzymes. Bioactivation to genotoxic metabolites. Drug Metab Dispos 26: 540-546.

81. Müeller SO, Lutz WK, Stopper H (1998) Factors affecting the genotoxic potency ranking of natural anthraquinones in mammalian cell culture systems. Mutat Res 414: 125-129.

82. Lang W (1993) Pharmacokinetic-metabolic studies with 14C-aloe emodin afte oral administration to male and female rats. Pharmacology 47 Suppl 1: 110-119.

83. De Witte P, Lemli J (1988) Metabolism of 14C-rhein and 14C-rhein anthrone in rats. Pharmacol 36: 152-157.

84. Gasiewicz TA, Neal RA (1982) The examination and quantitation of tissue cytosolic receptors for 2,3,7,8-tetrachlorodibenzo-p-dioxin using hydroxylapatite Anal Biochem 124: 1-11.

85. Venturini S, Tamaro M (1979) Mutagenicity of anthraquinone and azo dyes in Ames' Salmonella typhimurium test. Mutat Res 68: 307-312.

86. Wehner FC, Thiel PG, du Rand M (1979) Mutagenicity of the mycotoxin emodin in the salmonella/microsome system. Appl Environ Microbiol 37: 658-660.

87. Liberman DF, Schaefer FL, Fink RC, Ramgopal M, Ghosh AC, et al. (1980) Mutagenicity of islandicin and chrysophanol in the Salmonella/microsome system. Appl Environ Microbiol 40: 476-479.

88. Mereto E, Ghia M, Brambilla G (1996) Evaluation of the potential carcinogenic activity of Senna and Cascara glycosides for the rat colon. Cancer Lett 101: 79-83.

89. Brusick D, Mengs U (1997) Assessment of the genotoxic risk from laxative senna products. Environ Mol Mutagen 29: 1-9.

90. Mueller SO, Schmitt M, Dekant W, Stopper H, Schlatter J, et al. (1999) Occurrence of emodin, chrysophanol and physcion in vegetables, herbs and liquors. Genotoxicity and anti-genotoxicity of the anthraquinones and of the whole plants. Food Chem Toxicol 37: 481-491.

91. Müller SO, Eckert I, Lutz WK, Stopper H (1996) Genotoxicity of the laxative drug components emodin, aloe-emodin and danthron in mammalian cells: topoisomerase II mediated Mutat Res 371: 165-173.

92. Mueller SO, Stopper H (1999) Characterization of the genotoxicity of anthraquinones in mammalian cells. Biochim Biophys Acta 1428: 406-414. 
Citation: Mohammed MMD (2016) Structure Antimutagenicity Relationship of Anthraquinones. Nat Prod Chem Res 4: 228. doi:10.4172/23296836.1000228

93. Longo V, Amato G, Salvetti A, Gervasi PG (2000) Heterogenous effects of anthraquinones on drug-metabolizing enzymes in the liver and small intestine of rat. Chem Biol Interact 126: 63-77.

94. Wang HW, Chen TL, Yang PC, Ueng TH (2001) Induction of cytochromes P450 $1 \mathrm{~A} 1$ and $1 \mathrm{~B} 1$ by emodin in human lung adenocarcinoma cell line CL5. Drug Metab Dispos 29: 1229-1235.

95. Tanaka T, Kohno H, Murakami M, Shimada R, Kagami S (2000) Colitis-related rat colon carcinogenesis induced by 1-hydroxy-anthraquinone and methylazoxy methanol acetate (Review). Oncol Reports 7: 501-508.

96. Marec F, Kollárová I, Jegorov A (2001) Mutagenicity of natural anthraquinones from Rubia tinctorum in the Drosophila wing spot test. Planta Med 67: 127-131.

97. Battalora MSJ, Johnston DA, Di Giovannia J (1995) The effects of calcium antagonists on anthrone skin tumor promotion and promoter-related effects in SENCAR mice. Cancer Lett 98: 19-25.
98. Strickland FM, Muller HK, Stephens LC, Bucana CD, Donawho CK (2000) Induction of primary cutaneous melanomas in $\mathrm{C} 3 \mathrm{H}$ mice by combined treatment with ultraviolet radiation, ethanol and aloe emodin. Photochem Photobiol 72 407-414.

99. Mukhopadhyay MJ, Saha A, Dutta A, De B, Mukherjee A (1998) Genotoxicity of sennosides on the bone marrow cells of mice. Food Chem Toxicol 36: 937-940.

100. Martínez A, Urios A, Blanco M (2000) Mutagenicity of 80 chemicals in Escherichia coli tester strains IC203, deficient in OxyR, and its oxyR(+) parent WP2 uvrA/pKM101: detection of 31 oxidative mutagens. Mutat Res 467: 41-53.

101. Guerra Mde O, Mazoni AS, Brandão MA, Peters VM (2001) Toxicology of Lapachol in rats: embryolethality. Braz J Biol 61: 171-174.

102. De Witte P, Lemli L (1990) The metabolism of anthranoid laxatives. Hepatogastroenterology 37: 601-605. 